\title{
Construct the Community of IT Education and Break the Bottleneck of Rural School Educational Informationization
}

\author{
Dehua Kong \\ Shanxi Normal University, Linfen, China \\ Email: Kongdh73@126.com
}

Received May 1, 2012; revised June 19, 2012; accepted July 21, 2012

\begin{abstract}
Based on the current situation of rural educational informationization, my study found that the boost of rural elementary and secondary school's educational informationization needed the cooperation of higher normal universities and local education administrative department. The construction of "IT education community" is the key to step off the predicament. The practice application and effect in Gaoping City further proved that the cooperation project broke the bottleneck of rural elementary and secondary school's educational informationization.
\end{abstract}

Keywords: IT Education Community; Informationization Education; Education Development Service Area

\section{Introduction}

It is the requirement of education reform and important strategic action for the achievement of education modernization to drive to education modernization by education informationization, which helps to achieve the great-leap-forward development of basic education. Since 2000, governments at all levels and the education administrative department generally put their emphasis on basic education informatization. They have popularized the information technology education and fully implemented "The school passes project". In September 2003, the state council of the national education work conference held by the state council on further strengthening the rural education work put forward the decision: "the implementation of modern distance education in rural primary and secondary schools in urban and rural areas, promote the quality education project resources sharing”. Then equipped the rural schools with the corresponding information teaching equipment, let the economic weakness, the shortage of capital and primitive conditions of the rural primary and middle schools of education information construction get preliminary improvement. Relevant statistics show that by November 2007, the government of "modern distance education in rural primary and secondary schools project" a total investment of RMB11.1 billion yuan, and equipped with teaching equipment more than 440,000 sets of CD, covering 360,000 rural elementary school in the Midwest [1]. The "The school passes project" poured into nearly 100 billion in the education informationization. The implementation of the two countries project was a powerful impetus to the development of education in primary and middle school information, but in the process, the actual achievement and the desired objectives exist great gap. Why huge education information investment can't meet the expected benefits?

By investigation and analysis of the current education informationization in our school signed Education Research Base, I found the following problems in primary and middle schools education informatization: first of all, in the education informationization infrastructure, rural primary and secondary school facilities construction are not satisfactory. Campus network popularizing rate is very low and the network construction situation is weaker than city schools. In rural schools computer classroom and multimedia classrooms are far from meeting the needs of teachers and students. Secondly, in the resources construction, most of the rural school has just begun, and the accumulative total of funds in education information software resource input is a little. Many schools only bought a small amount of teaching VCD, meanwhile the teachers themselves made some courseware for classroom teaching. Due to failing to make resources integration, resources are limited for retrieval, and online information retrieval cannot be offered. What's more, in the teachers' construction, rural schools generally are lack of teachers; problems like heavy load of work and low information technology application level are very popular. Teacher's information technology abil- 
ity is not limited, so their courseware is quality less and unavailable. Furthermore, school funds are seriously in shortages, leadership in improper understanding. Therefore, primary and secondary school education informatization is related to the education system of each level, and requires a collective cooperation, to get out of the plight of rural primary and secondary school education at present, we must joint external strength, constructing "IT (information technology) education community”, to break through the bottleneck of rural school education informatization.

\section{Connotation of IT Education Community}

Social scientists endowed "community" with a connotation, "for specific purpose, people live together in a life group, organization or team”. This concept was transplanted into education field in the report titled "basic school, learning community” by Ernest L. Boyer, published in 1995. The report puts forward "school is the community of study". At present, the "learning community" "practice community" has become the focused topic in the education field at home and abroad, generally researchers coalescing group behavior theory, teachers' professional development theory and cooperation to its connotation [2].

Based on the situation of promoting the rural schools' education informationization and construction of teachers' professionalization, IT education community is mainly is made of the joint cooperation of university and primary and secondary schools community. IT education community refers to teachers (including network IT experts), normal school students (including IT education masters) and the primary and secondary school teachers in the normal colleges or universities with normal nature of the college acquire the common development in teaching, learning and research as a carrier. At the same time, governments at all levels and education administrative department should jointly establish "education development service area”, to provide a powerful system support for the construction of IT community education.

IT education community is essential to promote the quality education and the curriculum reform and is the needs of the change of the time which can effectively promote the process of basic education informationization.

\section{The Theory Model and Interpretation of "IT Education Community"}

After years of survey data analysis, in rural primary and secondary school education informatization is key to the development of informatization basic environment construction including hardware, network and software construction, digital teaching resource construction and teach- ers’ professional development, namely that the teacher has and curriculum integration necessary skills. For these props, strength comes from "education development service area”, IT teachers of normal universities and students, primary and secondary school teachers. The force source each has a different role. If each act is own way, it is helpless to promote education informatization for its deep advance. But if they can cooperate with each other, take the strength of each side and work unitarily, they can produce great overall efficiency. Therefore, I construct "IT education community", which will organize the four powers, as shown in Figure 1 below.

In this IT education community, with the support of "education development service area” by government at all levels and administrative department of education, the three main body-the college students, IT teachers, primary and secondary school teachers constitute a stable triangle through guide and cooperation. The main characteristics of the community are:

\subsection{Cooperative Consensus}

IT education community construction aims to promote rural education informationization, to promote of balanced development of basic education, and to promote teacher's professional development of information technology. Namely, combine the theory research with rich practice of education in middle and primary schools, start with the needs and problems solving of the two parties. Preference to any side will stop the good operation and sufficient work of "IT education community". Normal colleges and local education administrative department are responsible to the promotion of rural basic education informatization and development of professional development of teachers' information technology.

\subsection{Cooperation Project}

The construction of IT education community broke the boundaries between university and primary and secondary schools, to get all aspects, such as college IT teachers

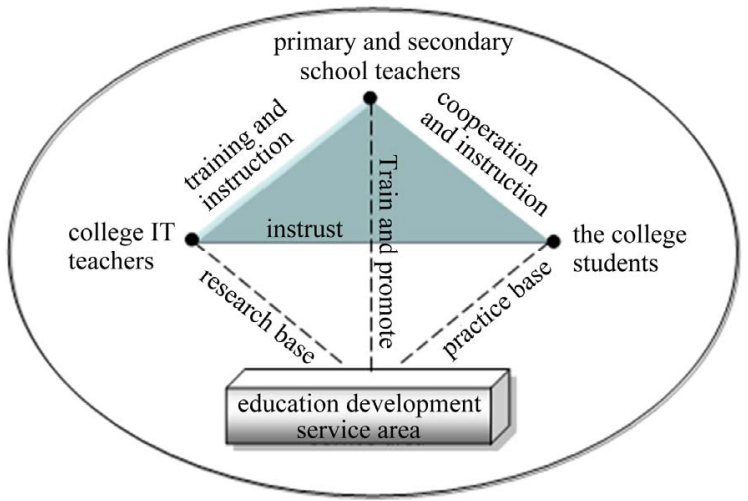

Figure 1. Model of "IT education community". 
and students, primary and secondary school teachers and education administrative department together in the form of alliance, to construct cooperative framework with the support of government, to set up cooperation institution, to found cooperative project and implement cooperative action. Considering substantive cooperation and close cooperation as signs, it aims at construction of valuable cooperation projects.

Following the guideline of "getting familiar with basic education, researching basis education, education, giving service to basic education and leading basic education", in November of 2006, our school started the project "substituted practice-exchange training", then successively signed training contracts with several cities and counties like Linfen, Yuncheng, Jincheng, Changzhi Lvliang etc. and established stable long-term cooperative teaching, learning and research base. In accordance with the agreement, our school is responsible for selecting and sending good normal school graduates to the base every semester, and providing the latest scientific research results and the information resources of teaching, selecting good teachers and related experts to the base to guide teaching and scientific research. At the same time a number of primary and secondary school teachers from the base schools would be replaced for four months of professional training and study in universities, the base schools are in charge of the training fees and students' practice post and accommodation, and regularly to organize college teachers and primary and secondary school teachers to carry out scientific research activities.

In the past five years, the project implementation has engaged in more than 280 rural primary and secondary schools, and has chosen 2554 students in ten batches to base schools, and 1088 teachers from primary and secondary school have been replaced with training study, at the same time, in summer and winter vacations all kinds of primary and secondary school teachers, principals have been organized for short-term training classes, including 4095 primary and secondary school teachers.

\subsection{Cooperation and Multi-Benefits}

Community formation takes reciprocal cooperation, common development, equality and mutual benefit, mutual complementary as principle of cooperation. By constructing the IT education community, under the strong support of "education development service area", the college IT teachers won the ongoing study bases, the primary and secondary school teachers won sustainable development and powerful guidance of theories, normal school students find education practice base. As a result, higher normal colleges could change the fact that preservice practical professional training is away from basic education and post-service training is lack of scientific profound and prospective theories.
In the process of cooperation, university IT teachers and normal school students take the latest information technology theories and informationization teaching resources to the bases, and find new research points in the basic education schools during the practice information technology teaching; Primary and secondary school teachers come to colleges to accept the frontier knowledge training and bring various problems to universities, and study together with university teachers. Education technology is the hot spot of the teachers to learn. Primary and secondary school teachers are in urgent need of it, especially how to apply information technology effectively to teaching and how to improve the classroom teaching efficiency. Through the practice-training-practice, primary and secondary school teachers improve their professional quality of information technology. In the past five years, the constant training in rotation, almost every teacher has been in training study, and equipped with certain amount of information teaching ideas and information technology skills. After training, teacher have been back to school, and put many idle informationization teaching equipment into use effectively.

\section{The Application Case of "IT Education Community"-Taking Gaoping as a Case Study}

Since the past five years of the application of "substituted practice-exchange training”, seven groups of students take turns to Gaoping for education practice, of each trainee teachers sent more than 70, distributed to 20 middle schools, including 3 urban middle schools, 4 township high school, 13 rural middle schools. Gaoping is a relatively developed district, $85 \%$ of high school have multimedia classroom, computer room, campus network, but the source is not too high with seldom use. Only when it comes to open classes or deal with inspections, they are used. There are scarcely information technology classes, in which the students usually play computer games, and not have no much teaching and learning, let alone the use of information technology to improve the students' practice ability and innovation ability. Digital instructional resources are only scattered optical disc resources, which almost can not directly put into use in teaching. The teachers are lack of redevelopment ability in information technology teaching courseware, which not only seriously hindered teachers' teaching in the implementation of the information, but also influenced the growth of the students.

\subsection{Carry Out Project Research and Promote the School Teaching Informationization}

In order to create a good atmosphere of the informationization teaching application, the schools have some incen- 
tive system, financially aiding teachers in information teaching research, or cooperate with the college teachers, for example how to use digital resources to optimize the classroom teaching, and how to integrate the information technology and curriculum, and so on. There are two projects aid every year, to improve the teachers' teaching research ability and at the same time promote the school teaching's informationization.

\subsection{Pre-Service and Post-Service Training for the Teachers' Information Accomplishment Promotion}

In addition to the compulsory courses like "college basic computer theory", "multimedia courseware production”, there are some new teaching curricula such as the integration of information technology theory with practice of the teaching in the course of three weeks of pre-job training, which primarily have the ability to carry out information teaching. The substituted teachers" also have the education technology course in a four months of training, including basic knowledge of IT, the use of office software, the search of network resources, to make multimedia courseware, the integration of information technology and curriculum, teaching research of information technology. This part accounts for a quarter of the content in the training. By training and study, primary and secondary school teachers are expected to grasp the basic teaching skills and information teaching research ability.

What's more, we also organized primary and secondary school teachers training and school principals training five times, and successively invited experts to Gaoping to attend lectures listening, teaching assessing, conducting teaching research team activities. After five years implementation, primary and secondary school teachers' teaching idea gradually changed, and began to try the integration of information technology with curriculum teaching reform. Almost every school held the multimedia teaching public class once or twice a week and teachers began to learn to make teaching courseware. By the organization of courseware competition, the school also improved teachers' study enthusiasm and operation ability, thus aroused their application of information technology in the classroom. In the process, some normal school students established the campus network and teaching resource database for the base. Through application practice, the advantages of various elements in the community have been developed, and organic cooperation contributed to target reaching.

\subsection{Tele-Collaborative Communication, Improve the Lifelong Learning Ability}

Directing at the problem that college IT teachers can't guide teaching at any time and place, we established a
B-learning teacher training platform. We organized subject experts and network experts to establish information teaching resource database, which help primary and secondary school teachers and students get access to the information technology teaching easily and quickly. Platform also provides interactive Blackboard function, to promote the teachers lifelong learning ability through the online chat rooms, online discussion by posting reading materials, exchange, and development of teaching resources by collective cooperation. According to the survey, by the year 2011, March 27, 169 people registered in the platform, 3092 logs published, 2912 comments article issued.

\section{Implementation Effect of "IT Education Community”}

On the basis of "IT education community", the rural primary and secondary school education informatization development has achieved substantial progress in the past five years.

\subsection{To Promote the Information Infrastructure Construction}

In the past five years, some good condition middle schools in Gaoping equipped every teacher with a laptop computer, and computer rooms are updated. They constructed group class preparation room, and gave students' computer room a network for information search on the Internet. In the construction of the school information infrastructure, "education development service area” played a very important role.

\subsection{Improve the Primary and Secondary School Teachers' Teaching and Application Ability}

Before the project was conducted, many teachers in Gaoping have classes with a textbook, a piece of chalk, a blackboard. But now everyone can use multimedia way in classroom teaching, with more than 95\% utilization rate. Since the establishment of B-learning teachers' training platform, teachers actively participate in online research, communicate with other teachers, even expose their own teaching courseware to Internet to share. By mutual re-exchange, re-share, reflective activities, teachers obtain sustainable development and theory progress, thus teachers' professional ability obtained and improved.

\subsection{Promote the Transformation from "Novice Teachers" to "Mature Teachers"}

Normal school students as "novice teachers", are not familiar with basic education condition, and are lack of pre-service psychological quality, the cooperation spirit 
and training, the information technology teaching skills haven't been exercised. In IT education community, through observation and imitation the experts' methods problems solving, they gradually make progress and become "mature teachers".

\subsection{The College Teachers Got Ongoing Study Base}

For today's teachers and education, a universal problem is: the disjointedness of pre-service training and postservice training, disjointedness of higher education and basic education. Higher college teachers with advanced education concept are used to researching in their bookroom, but due to the misunderstanding of the primary and secondary school teachers and their works, theory can't meet the need of practice. However, in IT education community, university teachers through the practice, the instruction and the test of new education theory, acquire the theory promotion and academic growing point based on their basic practice.

\section{Summary and Prospect}

Five years of practice show that the use of the "IT education community" can greatly promote the construction of the informatization in rural primary and secondary school education, such as information infrastructure improvement, and information resources perfection, teachers' teaching ability improvement, teachers' professional level, get a powerful impetus to the development of rural primary and secondary school education information. The rural education informatization development needs support from government and education administrative department at all levels as "education development service area” to go further.

\section{Acknowledgements}

This research was supported by "Eleventh Five-Year Plan” of Shanxi Education and Science under Grant No. GH-09201, and Research Fund projects of Shanxi Normal University under Grant No. YJ09009, and Education Reform Project of Shanxi Normal University under Grant No. SD2009YBKT-15.

\section{REFERENCES}

[1] The Modern Tele-Education Project Office in Rural Primary and Secondary Schools, "Set Up the BridgeChina's Modern Tele-Education Project in Rural Elementary and Middle Schools,” People’s Education Press, Beijing, 2007.

[2] W. P. Guo, "An Exploration on the Construction of Teachers' Education Community in Primary Schools," Continuing Education Research, No. 9, 2010, p. 91. 